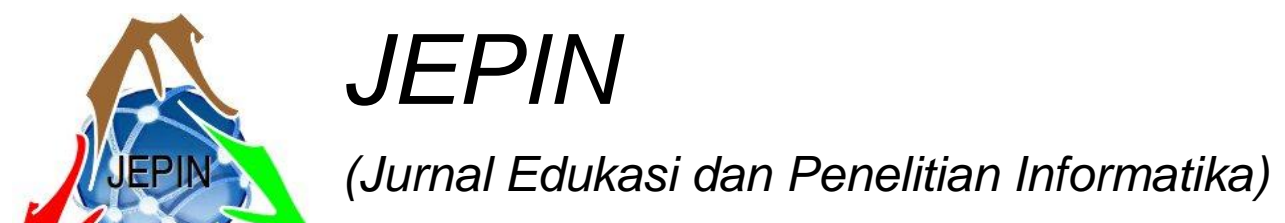

Vol. 6

\title{
Implementasi Algoritma Fuzzy C-Means Clustering Sistem Crowdfunding pada Sektor Industri Kreatif Berbasis Web
}

\author{
Wawan Gunawan ${ }^{\# 1}$, Bagus Seno Prasetyo Diwiryo ${ }^{\# 2}$ \\ ${ }^{\#}$ Teknik Informatika, Fakultas Ilmu Komputer, Universitas Mercu Buana \\ Jalan Meruya Selatan No. 1 Jakarta Barat 11650 \\ ${ }^{1}$ wawan.gunawan@mercubuana.ac.id \\ ${ }^{2}$ bagus. seno39@gmail. com
}

\begin{abstract}
Abstrak - Perkembangan teknologi setiap tahun semakin maju sehingga memiliki dampak terhadap kemudahan terhadap sektor industri kreatif. Dengan berkembangnya teknologi ini, memberi kemudahan untuk menggalang dana pada sektor industri kreatif berupa sebuah sistem crowdfunding. Pengimplementasian crowdfunding pada sektor industri kreatif dapat dijadikan sebagai alternatif penggalangan sumber pendanaan untuk anak - anak negeri. Maka dari itu, dibangun aplikasi berbasis web untuk memudahkan pengguna dalam melakukan penggalangan dana ataupun memberikan dana. Pada penelitian ini, peneliti dapat menggunakan data yang terkumpul pada aplikasi crowdfunding ini menjadi suatu informasi yang dapat dimanfaatkan. Salah satu informasi yang dapat diperoleh adalah kampanye project yang mendapatkan pendanaan terbanyak, terkecil dan belum didanai. Untuk mengetahui hal tersebut, maka dirancang suatu sistem aplikasi crowdfunding berbasis web dengan mengimplementasikan metode fuzzy $c$ means clustering sebagai metode untuk mengelola data-data yang telah terkumpul. Pengujian sistem pada hasil akhir sistem menggunakan metode fuzzy c-means clustering dengan menggunakan 13 contoh kasus uji, menunjukkan bahwa hasil perhitungan metode ini didapatkan output berupa 3 kriteria yaitu terbanyak $23,1 \%$ kampanye project, terkecil $38,5 \%$ kampanye project, dan belum didanai $38,5 \%$ kampanye project. Berdasarkan hasil analisa ini, algoritma fuzzy $c$ means clustering bekerja dengan sangat baik untuk mengetahui kampanye project mana saja yang dapat dikembangkan.
\end{abstract}

Kata kunci-Crowdfunding, Fuzzy C-Means Clustering, Industri Kreatif, Donation.

\section{Pendahuluan}

Industri kreatif di berbagai negara saat ini sedang berkembang dengan sangat pesat. Di Indonesia sendiri pada umumnya alternatif permodalan untuk bisnis startup pada sektor industri kreatif ini didapat dari angel investor, ataupun memanfaatkan pemberian dana dari pemerintah atau perusahaan besar[1][2].
Namun ada alternatif lain yang ternyata dapat membantu anak-anak negeri dalam melakukan penggalangan dana di sektor industri kreatif ini yaitu dengan metode Crowdfunding. Crowdfunding dapat diartikan sebagai bentuk pendanaan yang melibatkan orang banyak, atau dalam istilah orang Indonesia crowdfunding biasa disebut dengan patungan[3].

Di luar negeri beberapa inisiasi aktivitas crowdfunding telah mengalami kesuksesan besar seperti proyek riset, pengembangan, dan penjualan jam tangan cerdas pehble dan produk opal oleh FirstBuild melalui platform crowdfunding Kickstarter (Brown, Boon \& Pitt, 2016). Pada proyek jam tangan cerdas ini berhasil mencapai target pendanaan dalam waktu 2 jam oleh 70.000 pemberi dana (Brown et al., 2016).

Crowdfunding yang dimaksud dalam penelitian ini merupakan suatu bentuk penggalangan dana berbasis web dan akan terpublikasikan secara online[4][5][6].

\section{KAJIAN PUSTAKA}

Fuzzy clustering adalah metode untuk menentukan derajat keanggotaan, dan menggunakannya dengan cara memasukkannya ke dalam elemen data ke dalam satu kelompok cluster atau lebih. Hal ini akan memberikan informasi kesamaan dari masing - masing objek.

C-means clustering. Vektor dari fuzzy clustering, $\mathrm{V}=\{\mathrm{v}$ $, \mathrm{v}, \mathrm{v}, \ldots, \mathrm{v}\}$, merupakan sebuah fungsi objektif yang di defenisikan dengan derajat keanggotaan dari data $\mathrm{Y}$ dan pusat cluster Z. Fuzzy C-Means merupakan metode clustering yang memungkinkan suatu kumpulan data dijadikan anggota satu atau lebih cluster. Metode yang dikembangkan oleh Dunn dan Bezdek ini banyak digunakan dalam pengenalan pola (pattern recognition).

Algoritma fuzzy clustering c-means membagi data yang tersedia dari setiap elemen data lalu memasukkannya kedalam bagian dari koleksi cluster yang dipengaruhi oleh beberapa kriteria yang telah ditentukan [7][8].

Fuzzy Clustering merupakan salah satu metode analisis cluster dengan mempertimbangkan tingkat keanggotaan 
yang mencakup himpunan fuzzy sebagai dasar pembobot bagi pengelompokan. Metode ini merupakan pengembangan dari metode partitioning data dengan pembobotan fuzzy[9].

Berdasarkan penelitian sebelumnya bahwa penggunaan metode clustering Fuzzy C-Means atau Soft K-Means telah digunakan untuk melakukan pengelompokan atas mahasiswa berdasarkan jumlah kehadiran, dan dinyatakan bahwa terdapat jumlah rata-rata mahasiswa sebesar 19,51851852 yang merupakan kelompok tidak perlu pengawasan, sedangkan dengan rata-rata sebesar 84 merupakan kelompok yang membutuhkan pengawasan[8].

Selain itu Fuzzy C-Means juga telah digunakan dalam pemberian beasiswa kepada mahasiswa, dan dinyatakan dari 14 mahasiswa yang terdaftar untuk mendapatkan beasiswa terdapat 9 mahasiswa yang layak untuk menerima beasiswa dengan kecocokan dengan target sebesar 50\% [10].

\section{METODE PENELITIAN}

Pada tahap awal dilakukan pengumpulan data atau materi penulisan dengan cara :

1) Wawancara : Melakukan wawancara secara langsung dengan pihak penggalang dana, pemberi dana maupun startup yang menangani penggalangan dana agar data maupun bisnis prosesnya diperoleh secara tepat dan akurat.

2) Observasi : Dengan melakukan pengamatan secara langsung proses penggalangan dana pada bagian terkait yang akan disalurkan ke penggalang dana.

3) Literatur / Studi Pustaka : Penulisan dilakukan dengan cara mempelajari berbagai macam referensi pustaka yang menyangkut tentang aplikasi crowdfunding, terutama jurnal[11].

Bagian alur (flowchart) metode penelitian proses pembuatan crowdfunding dapat diilustrasikan pada gambar 1.

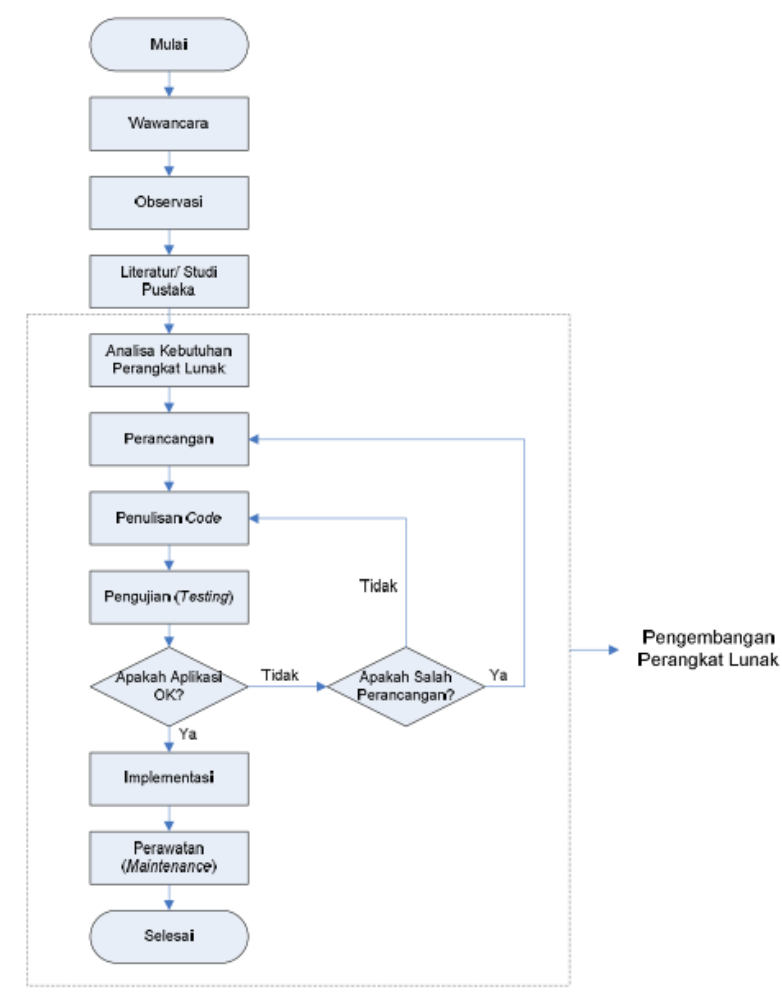

Gambar 1. Flowchart metodologi penelitian

Metode yang digunakan pada pengembangan penelitian ini menggunakan metode waterfall karena menggunakan fase one by one sehingga dapat meminimalkan terjadinya kesalahan dalam pengembangan sistem, seperti yang terlihat pada gambar 2 .

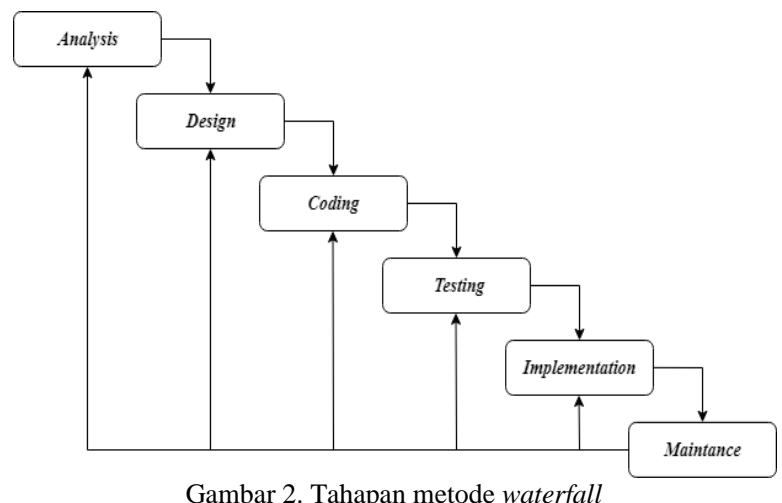

1) Analisa Kebutuhan (Analysis) : Dalam pengumpulan kebutuhan, disini berbasis pada perangkat lunak.

2) Perancangan (Design) : Ada 4 atribut untuk program yaitu: struktur data, arsitektur perangkat lunak, prosedur detail dan karakteristik antarmuka.

3) Penulisan Code (Coding) : Penerjemah ke bentuk yang dapat dimengerti oleh mesin, dengan menggunakan bahasa pemrograman $P H P$. 
4) Pengujian (Testing) : Testing difokuskan pada logika internal dari perangkat lunak, fungsi eksternal, dan mencari segala kemungkinan kesalahan baik itu dari sisi pembuatan code maupun pemeriksaan apakah aplikasi sudah berjalan dengan baik dan berfungsi sesuai dengan yang diharapkan.

5) Implementasi (Implementation) : Implementasi dilakukan setelah aplikasi lolos uji. Perangkat pendukung yang diperlukan tidak hanya hardware komputer, tetapi juga dukungan kebijakan dan sebagainya.

6) Perawatan (Maintenance) : Aplikasi yang telah diimplementasi diharapkan dapat dipakai dan tidak berhenti di tengah jalan. Agar dapat dipergunakan dengan semestinya, perangkat lunak dipelihara dengan memperhatikan beberapa aspek, diantaranya:

- Menangani perkembangan data dengan seiring berjalannya waktu.

- Menangani ancaman dari program penyusup lainnya.

- Memperbaiki apabila ditemukan error atau bug pada aplikasi yang sedang dijalankan.

- Penambahan fitur seiring dengan berjalannya waktu.

- Mampu menangani perkembangan dan kemajuan teknologi[12].

\section{HASIL DAN PEMBAHASAN}

\section{A. Perancangan}

Beberapa kriteria untuk menentukan tingkat penerima dana terbanyak atau tidaknya suatu proyek antara lain jumlah project $i d$, pemberi dana dan dana yang diterima. Data-data yang ada dalam website crowdfunding akan disimpulkan ke dalam tabel 1 untuk proses perhitungan fuzzy c-means.

TABEL I

CONTOH DATA CROWDFUNDING

\begin{tabular}{|c|c|c|}
\hline Project Id & $\begin{array}{c}\text { Dana } \\
\text { Terkumpul }\end{array}$ & $\begin{array}{c}\text { Pemberi } \\
\text { Dana }\end{array}$ \\
\hline 1 & $3 \%$ & 1 \\
\hline 2 & $0 \%$ & 0 \\
\hline 3 & $87 \%$ & 2 \\
\hline 4 & $42 \%$ & 1 \\
\hline 5 & $20 \%$ & 1 \\
\hline 6 & $0 \%$ & 0 \\
\hline 7 & $93 \%$ & 3 \\
\hline 8 & $0 \%$ & 0 \\
\hline 9 & $83 \%$ & 4 \\
\hline 10 & $0 \%$ & 0 \\
\hline 11 & $0 \%$ & 0 \\
\hline 12 & $10 \%$ & 1 \\
\hline 13 & $60 \%$ & 2 \\
\hline
\end{tabular}

Berdasarkan Tabel 1 dapat diketahui bahwa untuk project id 1, dana yang telah terkumpul sebanyak 3\% dari total dana yang dibutuhkan dengan total pemberi dana sebanyak 1 orang, dan seterusnya. Selanjutnya akan ditentukan masuk ke dalam cluster mana masing-masing project tersebut dengan menggunakan algoritma Fuzzy $C$ -
Means. Output yang diharapkan berupa tiga buah cluster, yaitu terbanyak, standar dan tidak ada.

Algoritma Fuzzy C-Means ini dapat kita gunakan karena karena memiliki cara yang tepat untuk memetakan suatu ruang input ke dalam ruang output dan memiliki nilai yang berkelanjutan.[10]

Untuk melakukan perhitungan dengan menggunakan algoritma Fuzzy C-Means, ditentukan nilai awal sebagai berikut :

1. Jumlah cluster $(c)=3$, yaitu terbanyak, standar dan tidak ada

2. Pangkat atau pembobotan $(w)=2$

3. Error terkecil yang diharapkan $(\xi)=10^{-5}$

4. Maksimum iterasi (MaxIter $)=50$

5. Nilai iterasi awal $(\mathrm{t})=1$

6. Fungsi obyektif awal $\left(P_{0}\right)=0$

Selanjutnya melakukan proses matriks sebagai partisi awal yang ditentukan secara acak dengan komponen $\mu_{i k}, i$ $=13$ dan $k=3$, sehingga dihasilkan matriks $U$ seperti di bawah ini

$$
U=\left[\begin{array}{lll}
0,632 & 0,087 & 0,151 \\
0,121 & 0,904 & 0,787 \\
0,171 & 0,636 & 0,811 \\
0,297 & 0,339 & 0,172 \\
0,787 & 0,094 & 0,124 \\
0,891 & 0,900 & 0,457 \\
0,218 & 0,450 & 0,256 \\
0,189 & 0,390 & 0,107 \\
0,365 & 0,902 & 0,834 \\
0,115 & 0,459 & 0,897 \\
0,826 & 0,514 & 0,763 \\
0,052 & 0,170 & 0,019 \\
0,754 & 0,967 & 0,347
\end{array}\right]
$$

Selanjutnya setelah didapatkan matriks partisi awal, langkah berikutnya adalah menentukan pusat cluster awal dengan proses perhitungan dapat dilihat pada tabel 2 , tabel 3 , dan tabel 4 untuk perhitungan pada masing-masing cluster.

TABEL II

CLUSTER PERTAMA

\begin{tabular}{|c|c|c|c|r|r|}
\hline $\begin{array}{c}\text { Cluster } \\
\mathbf{1}\end{array}$ & $\mathbf{X}_{\mathbf{i} \mathbf{1}}$ & $\mathbf{X}_{\mathbf{i} 2}$ & $\left(\boldsymbol{\mu}_{\mathbf{i} \mathbf{1}}\right)^{\mathbf{2}}$ & $\left(\boldsymbol{\mu}_{\boldsymbol{i} \mathbf{1}}\right)^{\mathbf{2} * \mathbf{X}_{\mathbf{i} \mathbf{1}}}$ & $\left(\boldsymbol{\mu}_{\boldsymbol{i} \mathbf{1}}\right)^{\mathbf{2} * \mathbf{X}_{\mathbf{i} \mathbf{2}}}$ \\
\hline 0,632 & $3 \%$ & 1 & 0,400 & 0,012 & 0,400 \\
\hline 0,121 & $0 \%$ & 0 & 0,015 & 0,000 & 0,000 \\
\hline 0,171 & $87 \%$ & 2 & 0,029 & 0,025 & 0,058 \\
\hline 0,297 & $42 \%$ & 1 & 0,088 & 0,037 & 0,088 \\
\hline 0,787 & $20 \%$ & 1 & 0,619 & 0,124 & 0,619 \\
\hline 0,891 & $0 \%$ & 0 & 0,793 & 0,000 & 0,000 \\
\hline 0,218 & $93 \%$ & 3 & 0,048 & 0,044 & 0,143 \\
\hline 0,189 & $0 \%$ & 0 & 0,036 & 0,000 & 0,000 \\
\hline 0,365 & $83 \%$ & 4 & 0,133 & 0,111 & 0,533 \\
\hline 0,115 & $0 \%$ & 0 & 0,013 & 0,000 & 0,000 \\
\hline 0,826 & $0 \%$ & 0 & 0,682 & 0,000 & 0,000 \\
\hline 0,052 & $10 \%$ & 1 & 0,003 & 0,000 & 0,003 \\
\hline 0,754 & $60 \%$ & 2 & 0,569 & 0,342 & 1,138 \\
\hline & & $\sum$ & 3,429 & 0,695 & 2,983 \\
\hline
\end{tabular}




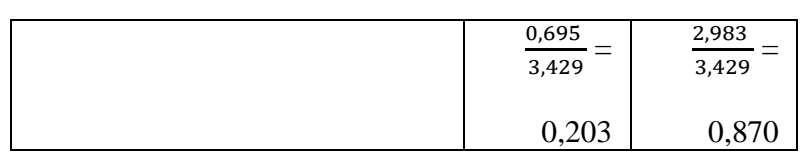

TABEL III

CLUSTER KEDUA

\begin{tabular}{|c|c|c|c|r|r|}
\hline $\begin{array}{c}\text { Cluster } \\
\mathbf{2}\end{array}$ & $\mathbf{X}_{\mathbf{i} \mathbf{1}}$ & $\mathbf{X}_{\mathbf{i}} \mathbf{2}$ & $\left(\boldsymbol{\mu}_{\mathbf{i} \mathbf{2}}\right)^{\mathbf{2}}$ & $\left(\boldsymbol{\mu}_{\mathbf{i} \mathbf{2}}\right)^{\mathbf{2} * \mathbf{X}_{\mathbf{i} \mathbf{1}}}$ & $\left(\boldsymbol{\mu}_{\mathbf{i} \mathbf{2}}\right)^{\mathbf{2} * \mathbf{X}_{\mathbf{i} \mathbf{2}}}$ \\
\hline 0,087 & $3 \%$ & 1 & 0,008 & 0,000 & 0,008 \\
\hline 0,904 & $0 \%$ & 0 & 0,817 & 0,000 & 0,000 \\
\hline 0,636 & $87 \%$ & 2 & 0,404 & 0,352 & 0,809 \\
\hline 0,339 & $42 \%$ & 1 & 0,115 & 0,048 & 0,115 \\
\hline 0,094 & $20 \%$ & 1 & 0,009 & 0,002 & 0,009 \\
\hline 0,900 & $0 \%$ & 0 & 0,809 & 0,000 & 0,000 \\
\hline 0,450 & $93 \%$ & 3 & 0,203 & 0,189 & 0,609 \\
\hline 0,390 & $0 \%$ & 0 & 0,152 & 0,000 & 0,000 \\
\hline 0,902 & $83 \%$ & 4 & 0,814 & 0,676 & 3,257 \\
\hline 0,459 & $0 \%$ & 0 & 0,211 & 0,000 & 0,000 \\
\hline 0,514 & $0 \%$ & 0 & 0,265 & 0,000 & 0,000 \\
\hline 0,170 & $10 \%$ & 1 & 0,029 & 0,003 & 0,029 \\
\hline 0,967 & $60 \%$ & 2 & 0,935 & 0,561 & 1,871 \\
\hline & $\sum$ & 4,771 & 1,831 & 6,705 \\
\hline & & 1,831 & 6,05 \\
& & & 4,771 & 4,771 \\
& & & 0,384 & 1,406 \\
\hline
\end{tabular}

TABEL IV

CLUSTER KETIGA

\begin{tabular}{|c|c|c|c|c|c|}
\hline $\begin{array}{c}\text { Cluster } \\
\mathbf{3}\end{array}$ & $\mathbf{X}_{\mathbf{i}} \mathbf{1}$ & $X_{\mathbf{i}} 2$ & $\left(\mu_{i 3}\right)^{2}$ & $\left(\mu_{i 3}\right)^{2 *} \mathbf{X}_{i 1}$ & $\left(\mu_{i 3}\right)^{2 * \mathbf{X}_{i 2}}$ \\
\hline 0,151 & $3 \%$ & 1 & 0,023 & 0,001 & 0,023 \\
\hline 0,787 & $0 \%$ & 0 & 0,620 & 0,000 & 0,000 \\
\hline 0,811 & $87 \%$ & 2 & 0,658 & 0,573 & 1,317 \\
\hline 0,172 & $42 \%$ & 1 & 0,030 & 0,012 & 0,030 \\
\hline 0,124 & $20 \%$ & 1 & 0,015 & 0,003 & 0,015 \\
\hline 0,457 & $0 \%$ & 0 & 0,209 & 0,000 & 0,000 \\
\hline 0,256 & $93 \%$ & 3 & 0,065 & 0,061 & 0,196 \\
\hline 0,107 & $0 \%$ & 0 & 0,012 & 0,000 & 0,000 \\
\hline 0,834 & $83 \%$ & 4 & 0,696 & 0,578 & 2,784 \\
\hline 0,897 & $0 \%$ & 0 & 0,805 & 0,000 & 0,000 \\
\hline 0,763 & $0 \%$ & 0 & 0,583 & 0,000 & 0,000 \\
\hline 0,019 & $10 \%$ & 1 & 0,000 & 0,000 & 0,000 \\
\hline \multirow[t]{4}{*}{0,347} & $60 \%$ & 2 & 0,120 & 0,072 & 0,240 \\
\hline & & $\sum$ & 3,836 & 1,300 & 4,606 \\
\hline & & & & $\frac{1,300}{3,836}=$ & $\frac{4,606}{3,836}=$ \\
\hline & & & & 0,339 & 1,201 \\
\hline
\end{tabular}

Dari hasil perhitungan yang dilakukan pada tabel 2 , tabel 3, dan tabel 4 maka diperoleh hasil pusat cluster $(V)$.

$$
V=\left[\begin{array}{ll}
0,203 & 0,870 \\
0,384 & 1,406 \\
0,339 & 1,201
\end{array}\right]
$$

Selanjutnya melakukan proses perhitungan untuk menentukan fungsi objektif menggunakan persamaan 1 untuk L1, persamaan 2 untuk L2, dan persamaan 3 untuk L3.

$$
\begin{aligned}
& {\left[\sum_{j=1}^{\sigma}\left(\mathrm{X}_{i j}-V_{1 j}\right)^{2}\right]\left(\mu_{i 1}\right)^{2}} \\
& {\left[\sum_{j=1}^{\sigma}\left(\mathrm{X}_{i j}-V_{2 j}\right)^{2}\right]\left(\mu_{i 2}\right)^{2}} \\
& {\left[\sum_{j=1}^{\sigma}\left(\mathrm{X}_{i j}-V_{3 j}\right)^{2}\right]\left(\mu_{i 3}\right)^{2}}
\end{aligned}
$$

TABEL V

PERHITUNGAN FUNGSI OBJEKTIF

\begin{tabular}{|r|r|r|r|}
\hline L1 & L2 & L3 & L1+L2+L3 \\
\hline 0,000633704 & 0,038878464 & 0,036725226 & 0,076237393 \\
\hline 0,003849643 & 0,763492582 & 0,508553036 & 1,275895261 \\
\hline 0,537087158 & 0,050151457 & 0,015339387 & 0,602578002 \\
\hline 0,000167163 & 0,007084484 & 0,052324542 & 0,059576189 \\
\hline 0,006073934 & 0,032248031 & 0,030670065 & 0,06899203 \\
\hline 0,25992486 & 1,636258242 & 1,219303845 & 3,115486948 \\
\hline 0,039006232 & 2,771254687 & 0,338655956 & 3,148916874 \\
\hline 0,607582433 & 0,257599476 & 0,471298693 & 1,336480602 \\
\hline 0,430079308 & 2,475514354 & 6,876372098 & 9,78196576 \\
\hline 0,045845681 & 0,039863682 & 1,005961334 & 1,091670696 \\
\hline 0,311319368 & 0,317688886 & 0,018357795 & 0,647366049 \\
\hline 0,013743846 & 0,039494822 & 0,084887994 & 0,138126662 \\
\hline 0,828970097 & 0,003803564 & 0,187672038 & 1,020445699 \\
\hline \multicolumn{4}{|c|}{ Fungsi Objective $=\sum$} \\
\hline
\end{tabular}

Selanjutnya melakukan proses perhitungan untuk menentukan Matriks Partisi U pada tabel 6 dengan menggunakan persamaan 4 untuk L1, persamaan 5 untuk L2, dan persamaan 6 untuk L3.

$$
\left[\sum_{j=1}^{\sigma}\left(\mathrm{X}_{i j}-V_{1 j}\right)^{2}\right]^{-1}
$$

$$
\begin{aligned}
& {\left[\sum_{j=1}^{\sigma}\left(\mathrm{X}_{i j}-V_{2 j}\right)^{2}\right]^{-1}} \\
& {\left[\sum_{j=1}^{\sigma}\left(\mathrm{X}_{i j}-V_{3 j}\right)^{2}\right]^{-1}}
\end{aligned}
$$


TABEL VI

PERHITUNGAN MATRIKS PARTIS

\begin{tabular}{|r|r|r|r|}
\hline \multicolumn{1}{|c|}{ L1 } & \multicolumn{1}{|c|}{ L2 } & \multicolumn{1}{l|}{ L3 } & LT=L1+L2+L3 \\
\hline 15,917 & 5,186 & 6,263 & 27,36567962 \\
\hline 1,182 & 0,544 & 0,560 & 2,287004089 \\
\hline 0,615 & 1,324 & 1,217 & 3,15621202 \\
\hline 24,110 & 9,610 & 9,090 & 42,80990383 \\
\hline 62,035 & 8,566 & 9,938 & 80,53912599 \\
\hline 1,182 & 0,544 & 0,560 & 2,287004089 \\
\hline 0,203 & 0,313 & 0,304 & 0,819644337 \\
\hline 1,182 & 0,544 & 0,560 & 2,287004089 \\
\hline 0,100 & 0,134 & 0,132 & 0,365843794 \\
\hline 1,182 & 0,544 & 0,560 & 2,287004089 \\
\hline 1,182 & 0,544 & 0,560 & 2,287004089 \\
\hline 27,327 & 6,473 & 7,791 & 41,58999817 \\
\hline 0,732 & 1,847 & 1,722 & 4,302240444 \\
\hline
\end{tabular}

Sehingga dapat diperoleh nilai matriks $U$ berdasarkan persamaan 7 sesuai dengan data yang disajikan pada tabel 6.

$$
\mu_{i j}=\mathrm{Lj} / \mathrm{LT}
$$

$$
U=\left[\begin{array}{lll}
0,582 & 0,190 & 0,229 \\
0,517 & 0,238 & 0,245 \\
0,195 & 0,420 & 0,386 \\
0,563 & 0,225 & 0,212 \\
0,770 & 0,106 & 0,123 \\
0,517 & 0,238 & 0,245 \\
0,247 & 0,382 & 0,371 \\
0,517 & 0,238 & 0,245 \\
0,272 & 0,366 & 0,362 \\
0,517 & 0,238 & 0,245 \\
0,517 & 0,238 & 0,245 \\
0,657 & 0,156 & 0,187 \\
0,170 & 0,429 & 0,400
\end{array}\right]
$$

Selanjtnya lakukan perhitungan untuk mengetahui apakah margin error yang diharapkan sudah terpenuhi atau belum sesuai dengan persamaan 8

$$
\left|P_{t}-P_{t-1}\right|<\varepsilon \text {, atau } t>\text { MaxIter }
$$

Sehingga didapat hasil untuk $P_{1}-P_{0}$ adalah

$$
\begin{aligned}
& =22,36373817-0 \\
& =22,36373817
\end{aligned}
$$

Mengingat hasil tersebut belum memenuhi persamaan 8, maka lanjutkan sampai proses iterasi ke-28 sehingga didapat matriks U menjadi

$$
U=\left[\begin{array}{lll}
0,086 & 0,901 & 0,013 \\
0,000 & 0,000 & 0,999 \\
0,562 & 0,124 & 0,314 \\
0,399 & 0,952 & 0,008 \\
0,339 & 0,960 & 0,006 \\
0,000 & 0,000 & 0,999 \\
0,953 & 0,034 & 0,013 \\
0,000 & 0,000 & 0,999 \\
0,931 & 0,046 & 0,023 \\
0,000 & 0,000 & 0,999 \\
0,000 & 0,000 & 0,999 \\
0,059 & 0,932 & 0,009 \\
0,115 & 0,627 & 0,257
\end{array}\right]
$$

Dari matriks U akan dapat diketahui project Id mana yang akan masuk pada cluster tertentu seperti yang ditunjukan pada tabel 7 .

TABEL VII

CLUSTER DERAJAT KEANGGOTAAN

\begin{tabular}{|c|c|c|c|c|r|}
\hline Project Id & $\boldsymbol{\mu}_{\mathbf{1}}$ & $\boldsymbol{\mu}_{\mathbf{2}}$ & $\boldsymbol{\mu}_{\mathbf{3}}$ & \multicolumn{2}{|c|}{ Cluster } \\
\hline 1 & 0,086 & 0,901 & 0,013 & 0,901 & 2 \\
\hline 2 & 0,000 & 0,000 & 0,999 & 0,999 & 3 \\
\hline 3 & 0,562 & 0,124 & 0,314 & 0,562 & 1 \\
\hline 4 & 0,399 & 0,952 & 0,008 & 0,952 & 2 \\
\hline 5 & 0,339 & 0,960 & 0,006 & 0,960 & 2 \\
\hline 6 & 0,000 & 0,000 & 0,999 & 0,999 & 3 \\
\hline 7 & 0,953 & 0,034 & 0,013 & 0,953 & 1 \\
\hline 8 & 0,000 & 0,000 & 0,999 & 0,999 & 3 \\
\hline 9 & 0,931 & 0,046 & 0,023 & 0,931 & 1 \\
\hline 10 & 0,000 & 0,000 & 0,999 & 0,999 & 3 \\
\hline 11 & 0,000 & 0,000 & 0,999 & 0,999 & 3 \\
\hline 12 & 0,059 & 0,932 & 0,009 & 0,932 & 2 \\
\hline 13 & 0,115 & 0,627 & 0,257 & 0,627 & 2 \\
\hline
\end{tabular}

\section{B. Pemodelan Sistem}

Kebutuhan fungsional akan dimodelkan secara grafis sebelum membangun aplikasi crowdfunding. Pemodelan tersebut akan lebih memudahkan pemahaman terhadap perancangan aplikasi yang akan dibuat. Pemodelan yang diterapkan pada penelitian ini adalah berorientasi objek dengan UML (Unified Modeling Language) sebagai penggambaran secara grafis[13][14][15].

Diagram yang dibuat antara lain use case diagram, activity diagram dan sequence diagram.

\section{Use Case Diagram}

Dalam use case diagram digambarkan interaksi antar pengguna aplikasi crowdfunding serta fungsi-fungsi dari setiap pengguna maupun admin dalam sistem yang akan dibuat dan dimodelkan seperti terlihat pada gambar 3 . 


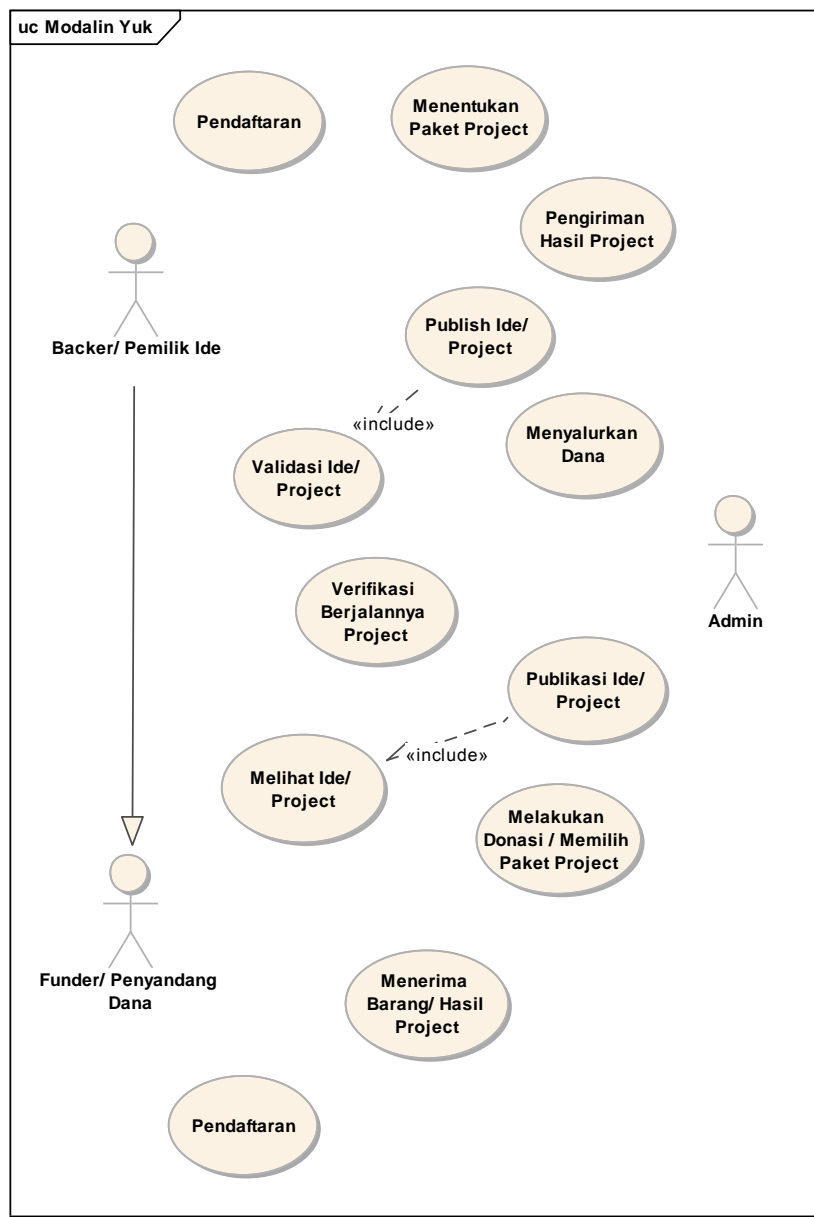

Gambar 3. Use case diagram aplikasi crowdfunding

\section{Activity Diagram}

Activity diagram menggambarkan suatu proses yang ada terdapat pada use case diagram aplikasi crowdfunding. Gambar 4 menunjukkan activity diagram dari aplikasi crowdfunding mulai dari melakukan penggalangan dana, pemberian donasi, publikasi kampanye project dan lain sebagainya.

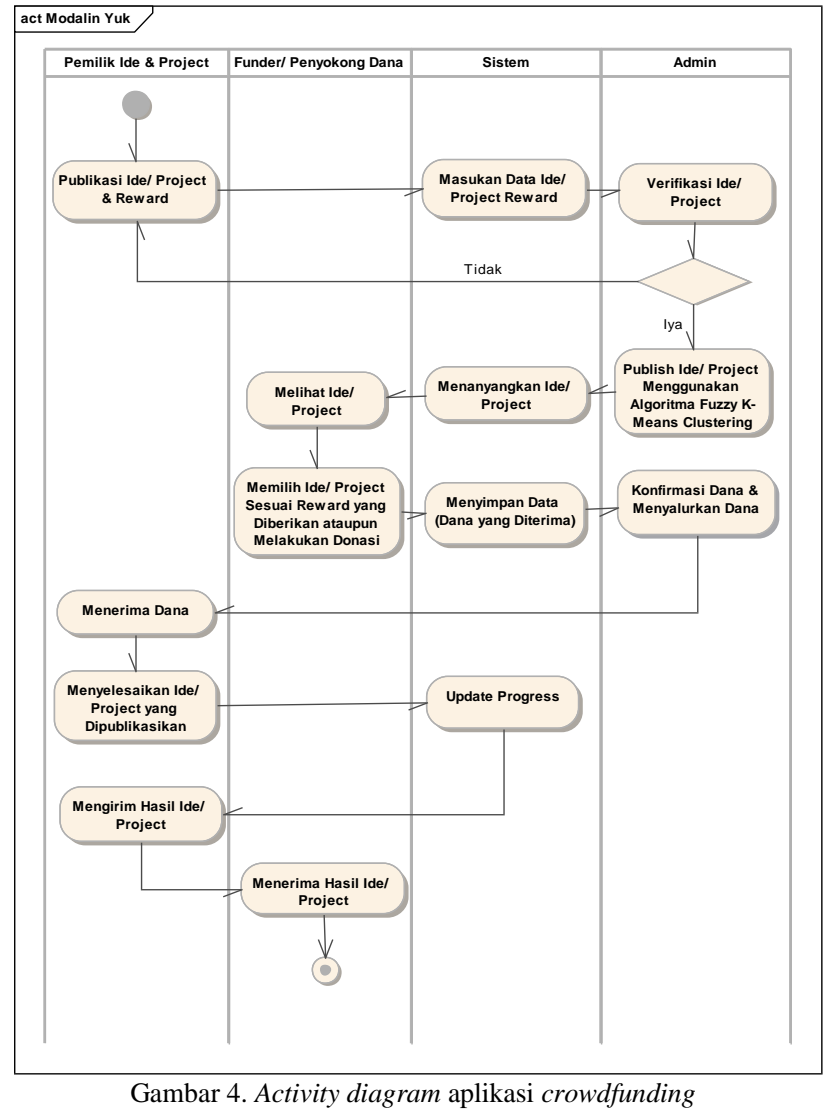

\section{Sequence Diagram}

Sequence Diagram menggambarkan prilaku suatu objek yang ada pada aplikasi crowdfunding. Pada sequence diagram ini juga dapat dilihat skenario yang terjadi di use case diagram. Sequence diagram dari publikasi suatu kampanye project ditunjukan pada gambar 5, sedangkan sequence diagram untuk pendanaan serta verifikasi kampanye project yang akan di publikasikan ditampilkan pada gambar 6.

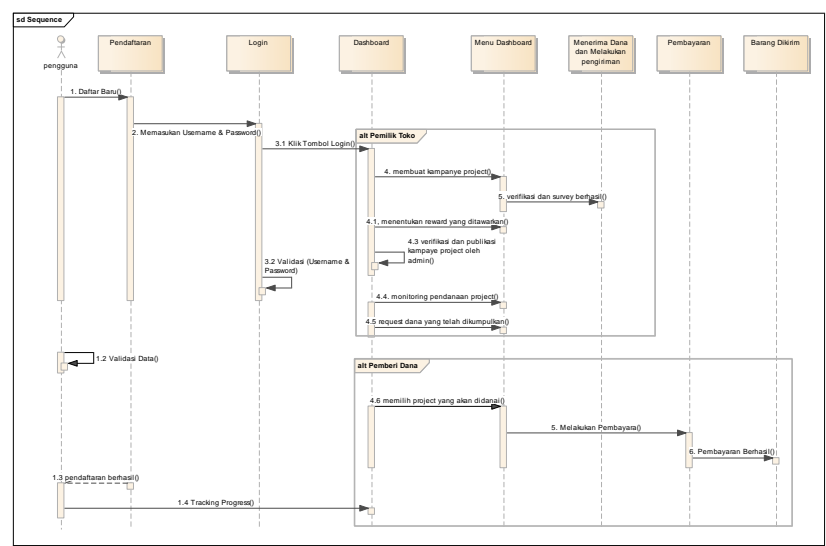

Gambar 5. Sequence diagram pengguna aplikasi crowdfunding 


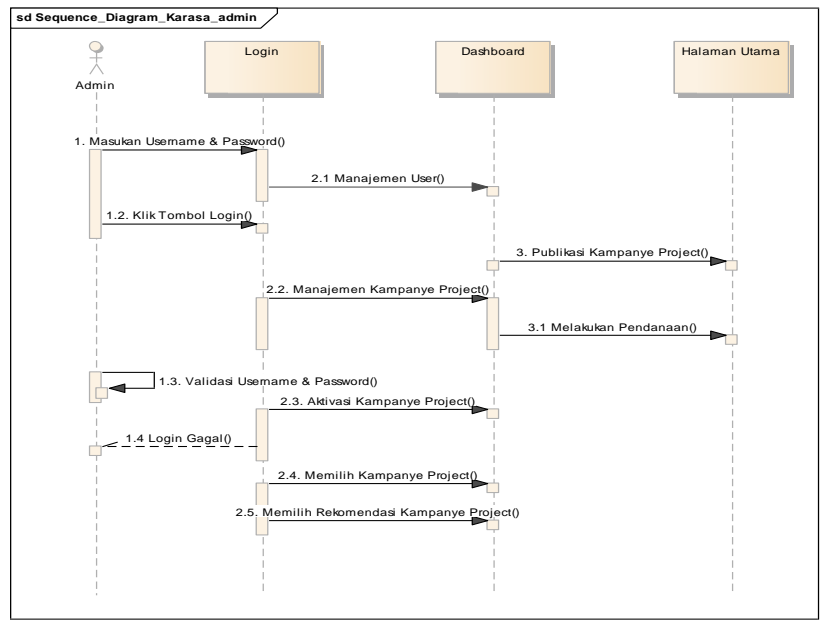

Gambar 6. Sequence diagram admin aplikasi crowdfunding

\section{Pemodelan Basis Data}

Relasi tabel merupakan suatu model untuk menjelaskan hubungan antar data dalam basis data berdasarkan objek dasar data yang mempunyai hubungan antar relasi. Relasi tabel aplikasi crowdfunding terlihat pada gambar 7 [16].

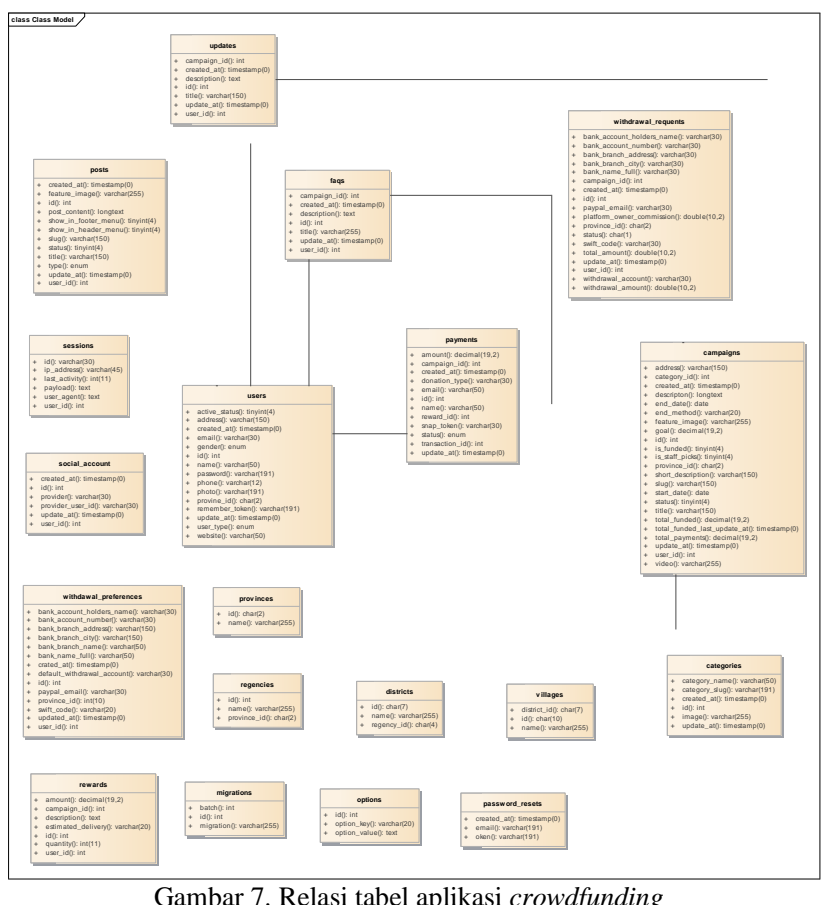

\section{Implementasi}

Implementasi merupakan tahap lanjutan dari website crowdfunding. Dalam implementasi website crowdfunding ini memiliki fungsionalitas terhadap 3 user diantaranya :

a. Pemilik ide atau kampanye project dapat melakukan penggalangan dana melalui platform yang disediakan dan menentukan paket dalam setiap project yang dikampanyekan.

b. Pemberi dana melakukan donasi atau memilih paket yang telah ditawarkan oleh pemilik ide atau project. c. Admin memanajemen user yang terdaftar dalam aplikasi, project yang akan di publikasikan dan lainnya.

Setelah website dibuat sesuai rancangan, maka dihasilkan aplikasi crowdfunding berbasis web dengan menampilkan halaman berdasarkan fungsionalitas masingmasing, seperti tampilan landing page yang ditunjukan pada gambar 8 .
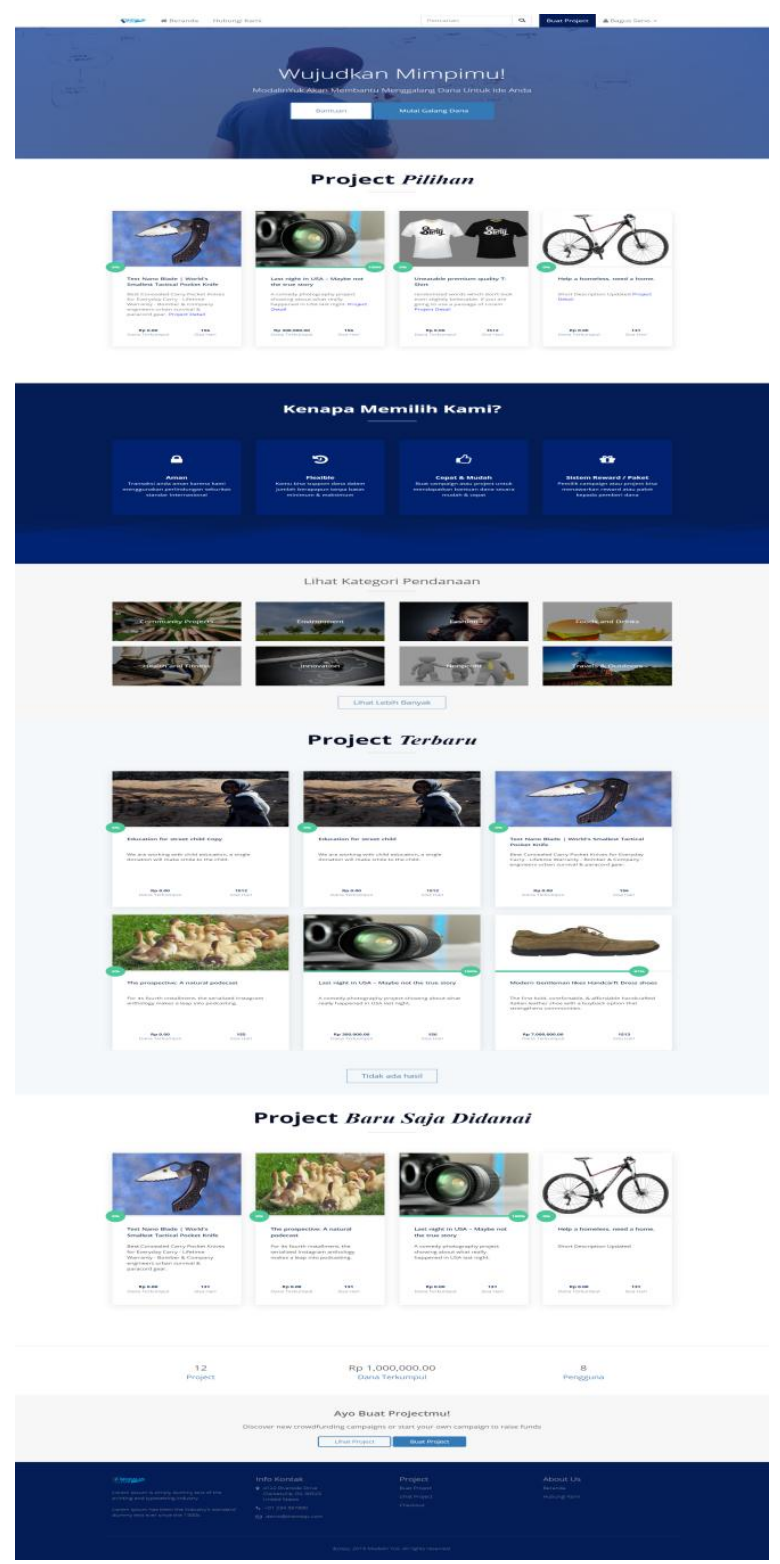

Gambar 8. Halaman utama

Sedangkan untuk dapat akses ke dashboard pengguna maupun admin, user harus melakukan login terlebih dahulu seperti ditunjukan pada gambar 9 . 


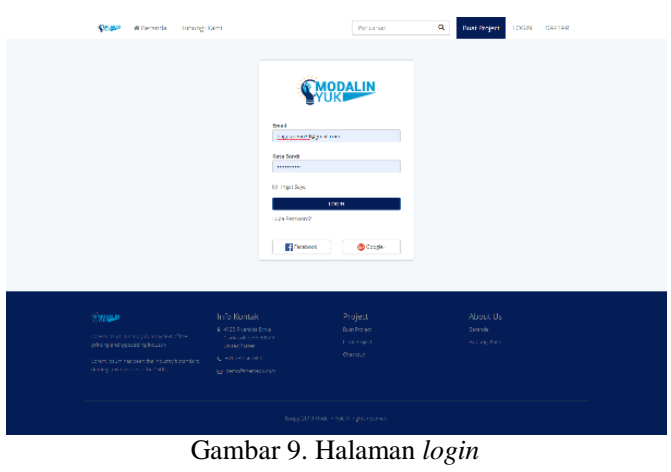

Untuk melakukan pendaftaran pengguna aplikasi crowdfunding ditunjukan pada gambar 10.

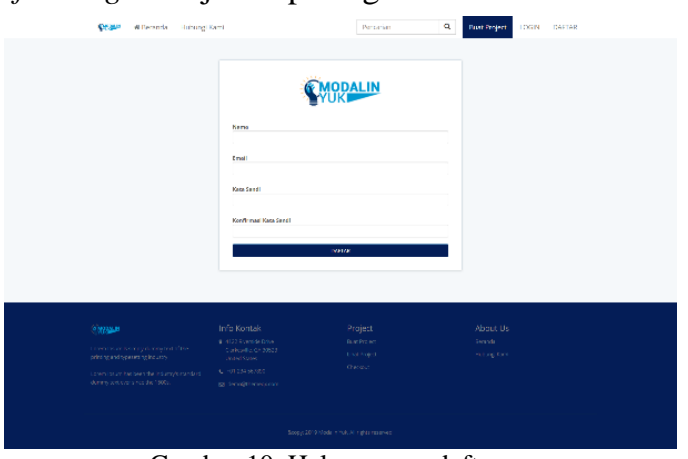

Gambar 10. Halaman pendaftaran

Halaman pembuatan kampanye project merupakan halaman untuk fungsionalitas pengguna, dalam halaman ini pengguna dapat melakukan pengajuan publikasi ide atau kampanye project, dan melengkapi beberapa komponenkomponen yang terdapat dalam kampanye project seperti ditunjukan pada gambar 11 .

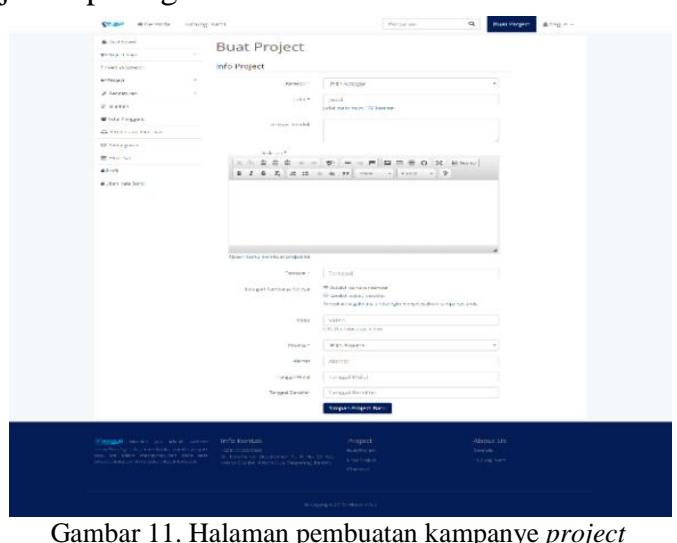

Halaman implementasi algoritma fuzzy c-means clustering dan beberapa fitur lainnya dalam bentuk dashboard untuk fungsionalitas admin ditunjukan pada gambar 12.

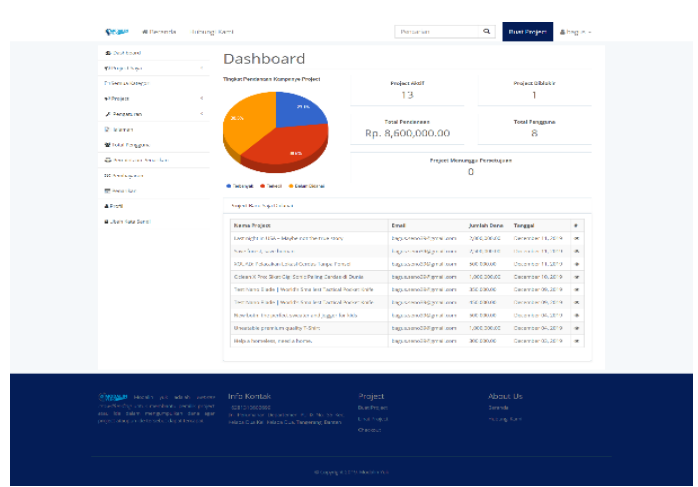

Gambar 12. Halaman dasboard (implementasi algoritma fuzzy $C$-means clustering)

\section{E. Analisis Hasil Perancangan Aplikasi Crowdfunding}

Analisis hasil dari perancangan aplikasi crowdfunding diantaranya sebagai berikut :

1. Hasil pengujian pada tahapan bisnis proses bahwa aplikasi crowdfunding dapat melakukan proses pembuatan kampanye project, pemberian dana maupun pemilihan paket dan mempublikasi kampanye project.

2. Berdasarkan hasil perhitungan menggunakan algoritma fuzzy c-means clustering dengan contoh data pada tabel 1 dan kriteria (terbanyak, terkecil, belum didanai) menunjukan bahwa sebanyak 3 kampanye project memperoleh dana sekitar $23,1 \%$ dengan kriteria terbanyak.

3. Berdasarkan hasil perhitungan menggunakan algoritma fuzzy c-means clustering dengan contoh data pada tabel 1 dan cluster (terbanyak, terkecil, belum didanai) menunjukan bahwa sebanyak 5 kampanye project memperoleh dana sekitar 38,5\% dengan kriteria terkecil.

4. Berdasarkan hasil perhitungan menggunakan algoritma fuzzy c-means clustering dengan contoh data pada tabel 1 dan cluster (terbanyak, terkecil, belum didanai) menunjukan bahwa sebanyak 5 kampanye project memperoleh dana sekitar 38,5\% dengan kriteria belum didanai.

\section{KESIMPULAN}

Berdasarkan hasil pengujian maupun analisa yang telah dilakukan maka dapat diambil kesimpulan sebagai berikut:

1. Metode perhitungan Fuzzy C-Means cocok digunakan pada aplikasi ini, karena dapat menghasilkan output berupa project mana yang dapat mengumpulkan dana terbanyak.

2. Aplikasi crowdfunding ini dapat dimanfaatkan sebagai sarana pemilik ide atau project dalam mewujudkan idenya.

3. Pembayaran atau pendanaan dapat dilakukan dengan mudah karena aplikasi crowdfunding sudah terintegrasi dengan salah satu payment gateway terbaik di Indonesia..

\section{REFERENSI}

[1] Rivani, M. Rizal, and R. S. Darwis, "ANALISIS KARAKTERISTIK PEMBIAYAAN UNTUK INDUSTRI KREATIF DI KOTA BANDUNG," Cybrarians $J$., vol. 4, no. 37, pp. 1-31, 2015 . 
[2] A. N. Rahmi, "Perkembangan industri ekonomi kreatif dan pengaruhnya terhadap perekonomian di indonesia," Semin. Nas. Sist. Inf., pp. 1386-1395, 2018.

[3] I. H. Serfiyani and C. Yustisia, "Perlindungan Hukum Sistem Donation Based Crowdfunding Pada Pendanaan Industri Kreatif Di Indonesia," J. Chem. Inf. Model., vol. 53, no. 9, pp. 1689-1699, 2013.

[4] T. E. Brown, E. Boon, and L. F. Pitt, "Seeking funding in order to sell: Crowdfunding as a marketing tool," Bus. Horiz., vol. 60, no. 2, pp. 189-195, 2017.

[5] F. Ferreira and L. Pereira, "Success factors in a reward and equity Equity Based Crowdfunding Campaign," 2018 IEEE Int. Conf. Eng. Technol. Innov., pp. 1-8, 2018.

[6] Y. Chen and B. Liu, "The optimal pricing strategy of the rewardbased crowdfunding product facing strategic consumers," 2017 IEEE Int. Conf. Grey Syst. Intell. Serv. GSIS 2017, no. 2013, pp. 379-384, 2017.

[7] S. Rudiarto, "IMPLEMENTASI ALGORITMA K-MEANS CLUSTERING PADA APLIKASI PENCARI PELANGGAN POTENSIAL PADA RESTORAN XYZ," vol. 2, no. 1, pp. 1-8, 2018.

[8] R. Rismanto, I. Fahrur Rozi, and A. Prasetyo, "Implementasi Fuzzy C-Means Untuk Prediksi Perilaku Mahasiswa Berdasarkan Jumlah Ketidakhadiran," SMARTICS J., vol. 3, no. 2, pp. 39-45, 2017.

[9] W. Sanusi, A. Zaky, and N. Afni, "Analisis Fuzzy C-Means dan Penerapannya Dalam Pengelompokan Kabupaten / Kota di Provinsi Sulawesi Selatan Berdasarkan Faktor- faktor Penyebab Gizi Buruk,"
J. Math. Comput. Stat., vol. 2, no. 1, pp. 47-54, 2018.

[10] D. L. Rahakbauw, V. Y. I. Ilwaru, and M. H. Hahury, "Implementasi Fuzzy C-Means Clustering Dalam Penentuan Beasiswa," BAREKENG J. Ilmu Mat. dan Terap., vol. 11, no. 1, pp. 1-12, 2017.

[11] M. S. Bathin and D. Ramayanti, "SOBATHUNI : Aplikasi Rumah Sewa Berbasis Web," J. Edukasi dan Penelit. Inform., vol. 5, no. 2, p. 183, 2019.

[12] W. Erawati, "Perancangan Sistem Informasi Penjualan Dengan Pendekatan Metode Waterfall," J. Media Inform. Budidarma, vol 3, no. 1, p. 1, 2019

[13] D. S. Maylawati, W. Darmalaksana, and M. A. Ramdhani, "Systematic Design of Expert System Using Unified Modelling Language," IOP Conf. Ser. Mater. Sci. Eng., vol. 288, no. 1, 2018.

[14] Y. Peng, "Overview of Object-Oriented System Development Method and UML Modeling Language," no. Iciss, pp. 27-33, 2019.

[15] R. Fauzan, D. Siahaan, S. Rochimah, and E. Triandini, "Use case diagram similarity measurement: A new approach," Proc. 2019 Int. Conf. Inf. Commun. Technol. Syst. ICTS 2019, pp. 3-7, 2019.

[16] F. T. Wulandari, "Pemodelan Basis Data Akademik Universitas Xyz Menggunakan Pendekatan Objek," JITU J. Inform. Technol. Commun., vol. 3, no. 1, pp. 52-57, 2019. 